\title{
The search for a new Tournaisian-Viséan boundary stratotype
}

\author{
1 Geological Survey of Belgium. Rue Jenner 13, B 1000 Bruxelles, Belgium. \\ 21, Whistler Point Rd., Westport, MA 02790, US \\ 3 Institute of Geology; Place L. Pasteur, 3, B-1348 Louvain-la-Neuve, Belgium \\ 4 Chinese Academy of Geological Sciences, 26 Baiwanzhuang Rd. Beijing 100037. China \\ 5 Nanjing Institute of Geology and Paleontology, 29 East Beijing Rd., Nanjing 210008, China \\ 6 Fysico-chemische Geology, Celestijnenlaan 200C, B-3001 Heverlee, Belgium \\ 7 Schwanenburgstr. 14, D-47804 Krefeld, Germany \\ 8 Polish Geological Institute, Warsawa. Poland \\ 9 British Geological Survey, Keyworth, Nottingham, NGI2 5GG, UK \\ 1) Department of Applied Geology, University of New South Wales, Sydney 2052, Australia \\ I/ Guizhou Bureau of Geology and Mineral Resources, Guiyang 550001, China
}

\begin{abstract}
Recent work indicates that a new biostratigraphic criterion and a new stratotype are required to define the Tournaisian-Viséan (T-V) boundary. Investigation of the $T$-V transition in Guangxi (South China) has provided data which give a new insight on the problem. The foraminifer Eoparastaffella provides a good new criterion for the establishment of the T-V boundary, based on its evolutionary stages. The sequence stratigraphy of this interval may also play a part in the recognition of the boundary. The idea of a type basin rather than a type section is put forward in preference to a single section as a better way of understanding the transition.
\end{abstract}

\section{Introduction}

At the last International Geological Congress in Beijing, the IUGS ratified selection of the Aidaralash section in northern Kazakstan (Davydov et al., 1995) and the Arrow Canyon section in southern Nevada (Brenckle et al., 1995) as global stratotypes, respectively, for the Carboniferous-Permian and Mid-Carboniferous boundaries. These decisions, along with the earlier selection of the DevonianCarboniferous boundary stratotype at La Serre. France (Paproth et al.. 1991), established the major horizons that define the extent of the Carboniferous and its division into upper and lower subsystems.

In anticipation of these events, Carboniferous Subcommission (SCCS) Chairman William Ramsbottom convened an international meeting at Provo, Utah, in 1989 to identify potential biostratigraphic horizons for refinement of global intra-Carboniferous correlations. Information presented at Provo (Brenckle and Manger, 1991) suggested that three levels each within the Lower and Upper Carboniferous merited further investigation. Two of these are now being examined by working groups (Paproth, 1996) under the chairmanship of George Sevastopulo (Trinity College, Dublin) and Elisa Villa (University of Oviedo, Spain) to define criteria for recognizing the Tournaisian-Viséan and Moscovian-Kasimovian boundaries.

This report deals with progress of the Tournaisian-Viséan houndary Working Group in its investigations in southeastern Asia. At the instigation of the SCCS, Luc Hance and Hou Hongfei in
November 1996 organized a field meeting in the Guangxi Zhuang Autonomous Region, South China (Figure 1), to acquaint the Working Group and other interested subcomisssion members with recent collaborative Chinese-Belgian research on the Tournaisian-Viséan boundary (Hance et al., 1996). The participants visited potential boundary sections to examine the lithostratigraphy and evaluate biostratigraphic criteria for boundary definition. Although of a reconnaissance nature, the field work confirmed the potential of that region for further boundary investigation. Results of the field examination and their implication for defining the Tournaisian-Viséan boundary are discussed below.

\section{Tournaisian-Viséan Boundary}

\section{Belgium}

Historically, Lower Carboniferous chronostratigraphic units have been defined on the rock succession exposed in southern Belgium, and in 1967 the 6th International Carboniferous Congress formally adopted a Tournaisian-Viséan boundary stratotype in the Dinant Basin. The base of the Viséan corresponded to the first black limestone intercalation in the Leffe facies at the Bastion Section (Subcommission on Carboniferous Stratigraphy, 1969). This level coincided with the first occurrence of the calcareous foraminifer genus Eoparastaffella (Conil et al., 1969) less than $1 \mathrm{~m}$ below the entry of the conodont Gnathodus homopunctatus (Groessens and Noël, 1977). An auxiliary boundary stratotype was later defined along the Route de Salet in the nearby Molignée Valley; this section became the type for the Moliniacian Stage at the base of the Viséan (Conil et al., 1977)

Sedimentation across the Tournaisian-Viséan boundary in southern Belgium extended south of the Brabant Oldland from a carbonate shelf or ramp into basinal facies. The type area is situated in the central part of the Dinant Synclinorium in deep water, restricted environments indicative of an intraplatform basin (the "Dinant Trough" of Conil in Robaszynski and Dupuis, 1983) or the distal part of a ramp (Lees et al., 1985). The growth of Waulsortian buildups on this ramp created paleohighs that influenced local sedimentation (Lees et al., 1985; Lees, 1997; Hance, 1988). Shallow water carbonates in the northern and eastern part of the synclinorium are separated from the deeper water facies by a narrow transition zone (Hance, 1988). 
Critical evaluation of the type area warrants the following conclusions:

1. The foraminiferal and conodont zonations are based mainly on material from the "Dinant Trough" and cannot be used successfully in the shallow water carbonates, whereas the reverse is true for brachiopod and rugose coral zonations.

2. Subsequent sedimentary research suggests that the appearance of guide fossils across the basin are facies-related and diachronous. A sea level drop of about $150 \mathrm{~m}$ took place during the late Tournaisian and early Viséan (Lees et al., 1985: Lees. 1997). It caused the decline and extinction of the Waulsortian buildups and affected fossil distribution in that successive appearances were controlled by changing bathymetry rather than evolution. The coincident entry of shallow water "Viséan" foraminifers and disappearance of deeper water "Tournaisian" conodonts are most likely ecologic rather than biostratigraphic. Moreover, stratigraphically significant Viséan taxa are present only in a few grainstone turbidites derived from the shallow shelf (Lees, 1997). In this context, biozonations have only local value (Hance, 1988; Hance et al., 1994; Kalvoda, 1994; Riley, 1995) and there are few levels that can be used for long distance correlation.

3. The use of unspecified Eoparastaffella as an index for the base of the Viséan is unsatisfactory. Indeed, the most primitive specimens of that genus (Vdovenko, 1964) are not found in the Dinant area. suggesting that its entry there was ecologically controlled and that older representatives of Eoparastaffella could be present in suitable environments elsewhere. It could also explain the occurrence of Eoparastaffella with the Tournaisian conodont Scaliognathus anchoralis (Groessens et al., 1982; Kalvoda, 1994; Riley. 1988).

4. The base of the Moliniacian Stage at its type section along the Route de Salet does not coincide with the base of the Viséan Series at the Bastion stratotype as originally thought (Conil et al.. 1977: Conil et al.. 1989). The correlation was based on the appearance of black limestones in both areas. Micropaleontological studies later showed that Eoparastaffella at the Route de Salet first occurs above the base of the Moliniacian stratotype, and it is that entry that correlates to the basal Viséan at Bastion. This discrepancy created a confusing and unacceptable situation in that the proposed earliest Viséan stage (Moliniacian) correlates partly with the latest Tournaisian.

These problems in the stratotype region led the TournaisianViséan Working Group to reassess criteria for defining the boundary. At the biennial SCCS meeting in Liége (Sevastopulo, 1993), suggestions were presented to (1) retain the present boundary, (2) seek a boundary coincident with the appearance of the conodont Scaliognathus anchoralis within the lineage $S$. praeanchoralis-S. anchoralis, or (3) recognize the boundary on the appearance of primitive archaediscid foraminifers. The latter two suggestions would move the boundary from its present position.

A fourth proposal was presented by Hance and Muchez (1995) at the 13th International Carboniferous-Permian Congress in Krakow. It is based on material from Guangxi and places the boundary at the appearance of an Eoparastaffella species with an outer subangular periphery (Morphotype 2 or E. simplex Vdovenko, 1964) succeeding an older species with a rounded periphery (Morphotype 1 or E. rotunda Vdovenko. 1964). This evolutionary succession is illustrated on Figure 2. Morphotype 2 species is present in the basal Viséan in the Dinant Basin. Usage of this definition would not significantly change the chronostratigraphic position of the historical boundary but would necessitate moving the stratotype from southern Belgium where Morphotype I is unknown.

\section{Guangxi Zhuang Autonomous Region, China}

From 1993 to 1996, the Chinese Academy of Geological Sciences and the Geological Survey of Belgium conducted joint research in Guangxi on the lithology and sequence stratigraphy of TournaisianViséan transition beds and their correlation to southern Belgium. The areas investigated are situated near the cities of Guilin and
Liuzhou in north-central Guangxi (Figure 1). During the Euly (arboniferous this region was a marine platform bordered on the north by the Yangtze Oldland and on the southeast by the ZengchengLeiqiong Oldland (Wu and Chen, 1989). Mixed siliciclastic-carbonate sediments were deposited along the margin of the Yangtze Oldland shoreward of a widespread carbonate platform. Slope and hasinal facies were restricted to narrow, intraplatform basins.

The most important sections crossing the Tournaisian-Vixéan boundary are located on Figure 1 and placed within the local statigraphic sequence in Figure 3. Platform carbonates are exposed at the Huaqiao Farm Section, slope facies at the Yajiao Section and basinal beds at the Pengchong Section.

Four successively younger foraminiferal associations were distinguished in the Tournaisian-Viséan transition beds in these sections (Figure 4). The oldest assemblage. Association A, is present in

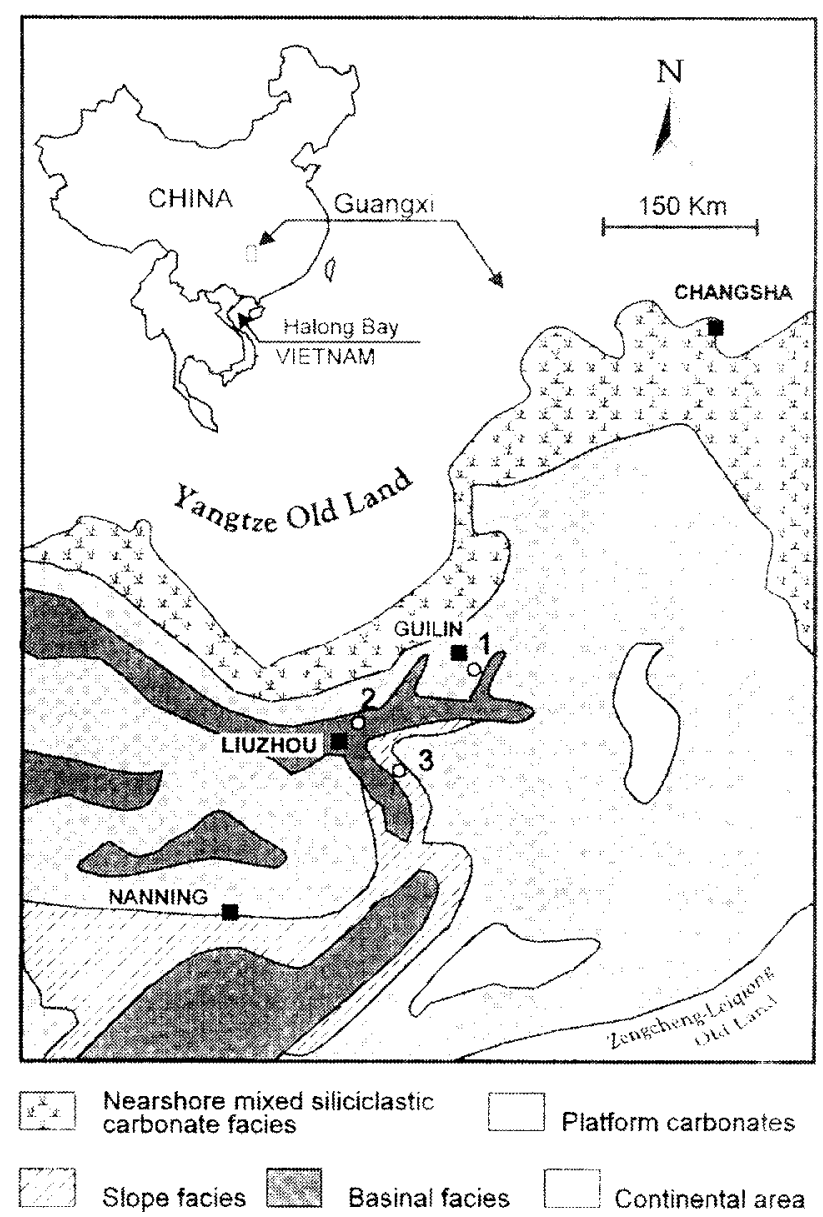

Figure I Palaeogeographic map of South China at the end of the Tournaisian (after Wu \& Chen 1989). 1. Huaqiao Farm; 2. Pengchong; 3. Yajiao.

the Yintang Formation at Huaciao Farm and in the Baping Formation at Yajiao. It exhibits a diverse upper Tournaisian fauna. Common elements throughout include Tetrataxidae, Latiendothronopsis, Granuliferella. Priscella, Spinoendolhyra. Tuberendothra. Condrustella. Eoforschia and very abundant Toumayellinae. Colonization by other foraminifers. including some that become more prominent in the Viséan. took place progressively starting with Bessiella, Florennella and dainellids; followed by Brmsia, Globoendothyra, Endospiroplectammina, and primitive Loebiichiidae; then Plectogyranopsis and Endothramopsis: and finally Pseudolituotubella and Pseudolituomba. The stratigraphic entry levels of these individual taxa relative to one another in the different sections, however, still need to be determined precisely. 
E.pseudochomata Vdovenko 1954
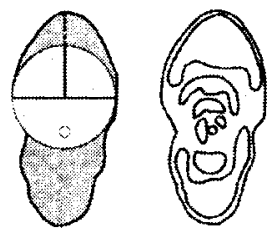

$e / r=0.65$

E. simplex Vdovenko 3956

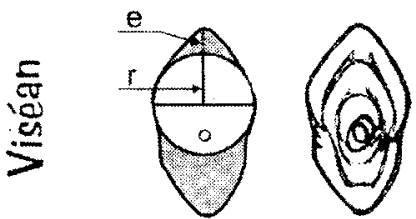

$e / r=0,58$

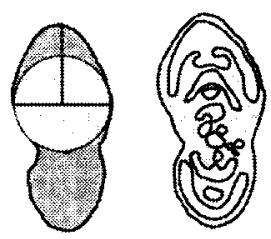

efr $=0,66$

\section{Morphotype 2}

More regular coiling, umbilici sligthly or well depressed. clear elevation of the last whorl giving rise to a subangulat periphery. Ratio $\mathrm{e} / \mathrm{r} \geq 0.5$

$$
\mathrm{e} / \mathrm{r}=0,5
$$

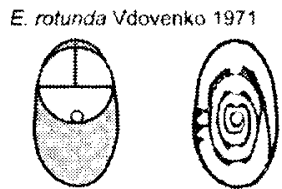

\section{Morphotype 1}

$e / r=0,22$

Figure 2 The peripheral outline in axial view can be used for calibrating the evolution of Eoparastaffella. The coefficient (e) reflects the elevation of the last whorl. Its ratio to the radius $(r)$ of the largest interior circle ranges between 0 in primitive specimens to 0.8 for evolved Eoparastaffella. For some species of Eostaffella, Pseudoendothyra and Millerella $e / r \approx l$ (or lightly higher), corresponding to an angular periphery with straight flanks. The base of the Viséan is recognized by Eoparastaffella specimens exhibiting an e/r value $\geq 0.5$, which separates Morphotypes 1 and 2 .

Association B is present in the three sections. It is distinguished from Association A by the simultaneous appearances of Laxoendothyra of the group L. laxa, Locblichia? of the group L? fragilis and Eoparastaffella Morphotype I followed by Mediocris.
Association $C$ has been recognized only in the Pengchong Member of the basinal Luzhai Formation. It either was not deposited or was eroded from the slope to shelf sections at Yajiao and Huaqiao Farm during a major sea level drop at the Tournaisian-Viséan boundary. The assemblage is characterized by the presence of more abundant Loeblichiidae and the appearance of Eoparastaffella Morphotype 2 in association with Morphotype 1. Eoendothyranopsis enters slightly above Eoparastaffella Morphotype 2. Septabrunsiininae, Endotaxis, Endothyra, Laxoendothyra of the group L. Iaxa, Bessiella and Florennella are the most abundant taxa. Endostaffella appears in the upper part of the stratigraphic sequence containing Association $\mathrm{C}$, whereas Laxoendothyra of the group $L$. laxa becomes scarce at that level. The assemblage is most likely allochthonous, having been derived from turbidites beds off the surrounding shelf platform.

Association D has been found only in the carbonate platform deposits of the Huangjing Formation at Huaqiao Farm where it rests unconformably on a paleokarst surface that represents a sequence boundary (Figure 3). Association B lies directly below, and the karst surface is thought to represent a time span equivalent to that needed to deposit Association $\mathrm{C}$ and the upper part of $\mathrm{B}$ in the deeper water sediments at the Pengchong Section (Figure 4). Association D is not diverse but contains new taxa including Eostaffella and Endothyra of the group E. bowmani. Transitional forms between Eoparastaffella and Eostaffella exist here as well as in southern Belgium (Conil and Naum, 1977). Brunsia, Spinobrunsiina (?=Urbanella). and Mediocris are abundant in Association D and Laxoendothyra of the group L. laxa is scarce.

These associations can tentatively be correlated to the established Franco-Belgian foraminiferal $(\mathrm{Cf})$ and conodont $(\mathrm{Cc})$ zonations of Conil et al. (1977, 1991) shown in Figure 4. Association A. which preceeds entry of the Eostaffellidae and Pseudoendothyridae. is late Tournaisian. It contains the conodonts Scaliognathus anchoralis europensis and Hindeodella segaformis of the $\mathrm{Cc} 3 \mathrm{con}-$ odont zone and is most likely time equivalent to foraminiferal zone Cf3 (Conil et al., 1989). The latter contains very few taxa in Belgium and is dominated by Tetrataxis, Endotaxis and Eotextularia diversa. Eoparastaffella Morphotype 1 coexists with S. anchoralis europensis in Association B, which probably equates to the Cf 401 Subzone at the top of the Tournaisian.

The lower part of Association C contains the first Eoparastaffella Morphotype 2 , the same form within the Dinant Basin where its appearance characterizes the $\mathrm{Cf} 4 \alpha_{2}$ Subzone at the base of the Viséan. Younger elements in Association $C$ include Endostaffella and Koskinobigenerina, the latter of which is unknown below the Cf5 Zone in western Europe. However, the overall composition of the assemblage and the lack of archaediscids suggest that Association $\mathrm{C}$ is no younger than $\mathrm{Cf} 4$.

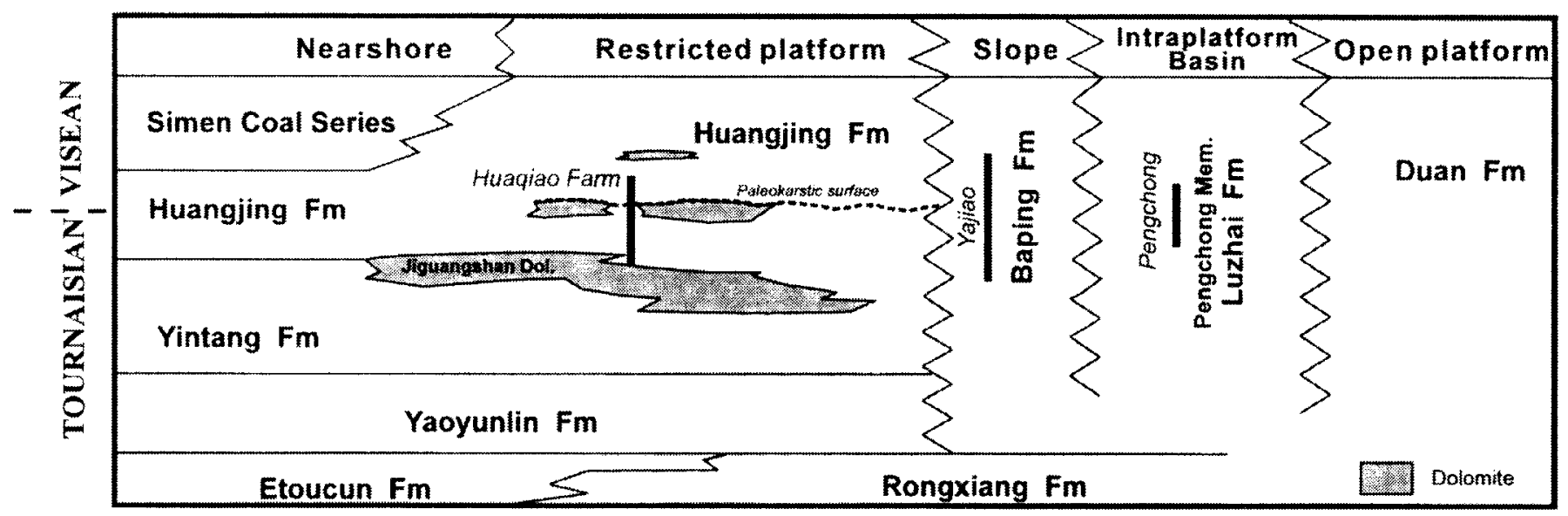

Figure 3 Lower Carboniferous lithostratigraphy of Guangxi and stratigraphic position of the Huaqiao Farm, Yajiao and Pengchong sections. 
Association D is difficult to correlate to Belgium because of an undiversified fauna lacking useful indices. The occurrence of Eostaffella indicates a position above $\mathrm{Cf} 4 \alpha 2$, but no microfossils have been found that definitively correlate to $\mathrm{Cf} 5$ or younger zones. As indicated in Figure 4, the upper part of Association C in the basinal beds may be equivalent to the lower part of Association $D$ on the platform. This cotrelation is supported by the entry of Endostaffella, a scarcity of Laxoendothyra of the group $L$. laxa and the occurrence of evolved Eoparastaffella in both areas.

\section{Discussion}

After 10 days examining outcrops and discussing the various options for Tournaisian-Viséan bounday selection, the field trip participants unanimously agreed on the following points.

1. It is appropriate to keep the Tournaisian-Viséan boundary at a stratigraphic level consistent with its traditional placement in the Dinant type region of southern Belgium. An alternative boundary definition based on the appearance of the conodont Scaliognathus anchoralis is unacceptable because it would lower the boundary, thus placing long recognized Tournaisian beds in the early Viséan. Conversely, a boundary based on the entry of primitive archaediscid foraminifers would raise the boundary, forcing traditional Viséan strata into the Tournaisian. Furthermore, at many localities in Eurasia the first archaediscids encountered are more advanced than the primitive members (Viseidiscus, Planoarchaediscus) so that a more consistent level for boundary correlation would be at the appearance of Uralodiscus rotundus. This species enters stratigraphically above the first occurrence of primitive forms and its use would raise the boundary to an even higher level. Another objection to a $U$. rotundus boundary is that the genus has not been reported from the Western Hemisphere

2. The change from Eoparastaffella Morphotype 1 to Morphotype 2 warrants consideration as a boundary-defining event. The proposal is attractive because the morphologic change takes place within a demonstrable evolutionary lineage and approximates the traditional boundary in Belgium. Rigorous species concepts need to be developed through shape analysis of the test periphery (Figure 2), precise definition of other morphologic features, and comparison with established species within the genus. Thus far the stratigraphic overlap of these ancestor-decendant morphotypes has been observed only in the basinal beds at Pengchong. The same relationship must be recognized widely before the evolutionary event separating the two morphotypes can be used to define the Tournaisian-Viséan boundary.

3. Sedimentation across the Tournaisian-Viséan boundary has been strongly influenced by sea-level fluctuations in Eurasia and possibly worldwide. The boundary should therefore not be defined only in terms of biostratigraphic changes but also be related to sequence stratigraphic events that may be applicable for global correlation. Results from South China suggest that a major unconformity occurs in the platform areas and that this event is bracketed by the transition of Eoparastaffella Morphotype 1 below and Eoparastaffella Morphotype 2 above. This same unconformity is present in similar settings in Western Europe and the Former Soviet Union (Riley 1990 and Riley et al. 1995).

4. A boundary concept based on one biostratigraphic event within a single stratotype is too restrictive. Such a criterion is often difficult or impossible to apply in other sedimentary regimes. An approach based on the study of a type basin rather than a type section would produce more satisfactory results in defining the TournaisianViséan boundary. Primary and auxiliary stratotypes chosen from representative depositional environments within the basin would facilitate correlation of shallow and deeper-water facies and integration of biozonations based on different fossil groups.

5. Can central Guangxi be considered as the type basin? The data from this area have greatly clarified our understanding of Tournaisian-Viséan boundary events, but the continuous sedimentary

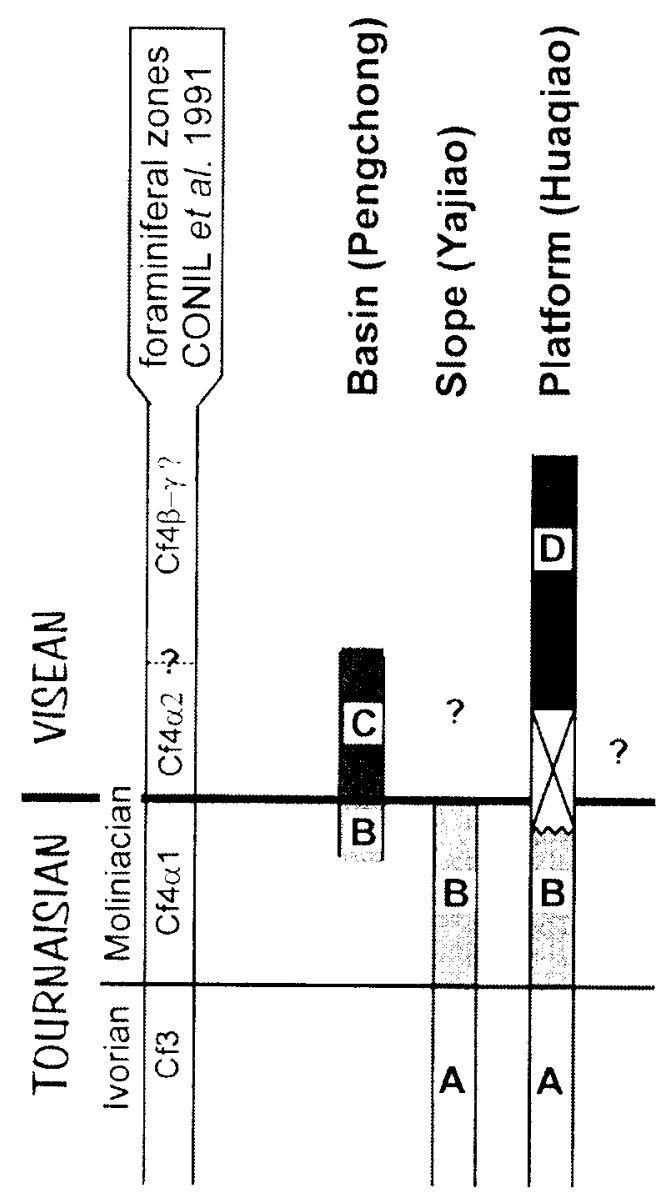

Figure 4 Foraminiferal associations recognized in the Tournaisian-Viséan transitional strata of Guangxi and their correlation with the Belgian succession.

sequences in the intraplatform basins are restricted. Fossil assemblages are not diverse, and information on such groups as ammonoids, deep-water trilobites and brachiopods is scant. Future research within the region should be directed to more open marine basins further south in China.

\section{Acknowledgements}

L. Hance has received a travel grant from the Belgian National Fund for Scientific Research. N. Riley publishes with permission of the Director of the British Geological Survey NERC and gratefully acknowledges receipt of a Royal Society travel award.

\section{References}

Brenckle, P L, Baesemann, J F. Lane, H R, West, R R, Webster, G D. Langenheim. R L, Brand, U. and Richards, B C, 1995, Arrow Canyon, The Mid-Carboniferous boundary stratotype: Abstracts, 13th International Congress on Carboniferous-Permian. Krakòw. Polish Geological Institute, $164 \mathrm{pp}$.

Brenckle, P L., and Manger. W L, eds., 1991, International Correlation and Division of the Carboniferous System: Courier Forschungsinstitut Senckenberg, v. $130,350 \mathrm{p}$.

Chishlom, J L, Charsley, T J, and Aitkenhead. N, 1988, Geology of the Country around Ashbourne and Cheadle: British Geological Survey Memoir. Sheet $124,159 \mathrm{p}$

Conil, R, and Naum. C. 1977, Les foraminitères du Viséen moyen, V2a aux environs de Dinant. Annales de la Société géologique de Belgique, 99. pp. 109-142. 
Conil, R, Austin, R L, Lys, M, and Rhodes, F H T, 1969, La limite des étages Tournaisien et Viséen au stratotype de l'assise de Dinant. Bulletin de la Socivété belge de Géologie, v. 77, pp. 39-67.

Conil, R, Groessens, E, and Pirlet. H, 1977, Nouvelle charte stratigraphique du Dinantien type de la Belgique. Annales de la Société géologique du Nord, v. 96, pp. 363-371.

Conil, R. Groessens, E, Laloux M. and Poty E, 1989, La limite TournaisienViséen dans la région-type. Annales de la Société géologique de Belgique, v. 112, pp. 177-189.

Conil, R, Groessens, E. Laloux, M. Poty. E, and Tourneur, F, 1991, Carboniferous guide foraminifers, corals and conodonts in the Franco-Belgian and Campine Basins. Courier Forschungsinstitut Senckenberg, v. 130, pp. 15-30.

Davydov, V. L., Glenister, B. F., Spinosa, C., Ritter, S. M., Chernykh, V. V., Wardlaw, B. R., and Snyder, W. S., 1995, Proposal of Aidaralash as GSSP for the base of the Permian System: Permophiles, no. 26, p. 1-9.

Groessens, E, and Noel, B, 1977, Etude litho- et biostratigraphique du Rocher du Bastion et du Rocher Bayard Dinant. Symposium Namur 1974, Publication 15, pp. 1-17.

Groessens, E., Conil, R. and Hennebert, M., 1982, Le Dinantien du sondage de Saint-Ghislain. Mémoire explicatif de la Carte géologique et minière de la Belgique, v. 22, 137 pp.

Hance, L, 1988, Le Moliniacien (Viséen inférieur) du Synclinorium de Dinant depuis la région dinantaise jusqu'à la vallée de l'Ourthe (Belgique). Mémoires de l'Institut géologique de l'Université de Louvain, v. $34,90 \mathrm{pp}$

Hance, L, and Muchez, P, 1995, Study of the Tournaisian-Viséan transitional strata in South China (Guangxi). XIII International Congress on Carboniferous-Permian, Krakòw, Poland., 28 Aug.- 2 Sept. 1995. Abstracts, p. 51 .

Hance, L, Laloux, M, Muchez, P, Groessens, E, Peeters, C, and Poty, E, 1994. An outline of the Moliniacian (upper Tournaisian-lower Viséan) in southern Belgium. Introduction to a field excursion in honour of Prof. Dr. Raphaël Conil - 12 October 1991. Mémoires de l'Institut géologique de I'Université de Louvain, v. 35, pp. 27-50.

Hance, L.. Hou H., Muchez. P., Coen, M., Groessens, E., Wu X., and Xu S., 1996, Field meeting on the Tournaisian-Viséan transition in South China: IUGS Subcommission on Carboniferous Stratigraphy, Working Group on the Tournaisian-Visean Boundary, Guidebook, 51 p.
Kalvoda, J, 1994, Comments on possible levels for Lower Carboniferous subdivision and results from Moravia. Geobios, v. 27, pp. 615-619.

Lees, A, Hallet, V, and Hibo, D, 1985, Facies variation in Waulsortian buildups, 1 ; a model from Belgium. Geological Journal, 20, pp. 133-158.

Lees, A. 1997.. Biostratigraphy, sedimentology and palaeobathymetry of Waulsortian buildups and peri-Waulsortian rocks during the late Tournaisian regression, Dinant area, Belgium. Geological Journal, 32, 1-36.

Paproth, E, 1996. Minutes of the SCCS Meeting. Krakow, 1995: Newsletter on Carboniferous Stratigraphy, v. 14, p. 4-6.

Paproth, E. Feist, R, and Flajs, G, 1991, Decision on the Devonian-Carboniferous boundary stratotype: Episodes, v. 14., p. 331-336.

Robaszynski, F and Dupuis, C, 1983, Belgique in Guides géologiques régionaux. Masson. Paris.

Riley, N J, 1990, Stratigraphy of the Worston Shale Group (Dinantian), Craven Basin, northwest England. Proceedings of the Yorkshire Geological Society, 48: 163-187.

Riley, N J, 1995, Foraminiferal biostratigraphy of the Chadian stage stratotype (Dinantian), Chatburn, Northwest England. Bulletin de la Société belge de Géologie, v. 103, pp. 13-49.

Riley, N J, Kusina, L, and Nemirovskaya, T, 1995, Correlation of major sequence breaks in the Lower Carboniferous of the UK and the Former Soviet Union (FSU). XIII International Congress on Carboniferous-Permian, Krakòw, Poland, 28 Aug. - 2 Sept. 1995. Abstracts, p. 121.

Riley, N J, in Chisholm, J L, Charsley, T J, and Aitkenhead, N, 1988 (ed.), Geology of the Country around Ashbourne and Cheadle, British Geological Survey Memoir, Sheet 124, pp. 10, 21, 23.

Sevastopulo, G, 1993, Report on Project Group 2: a mid "Lower Carboniferous" boundary. Subcommission on Carboniferous Stratigraphy, Newsletter no 11 , pp. 7-8.

Subcommission on Carboniferous Stratigraphy, 1969, Report of the 6th International Carboniferous Congress, Sheffield, 1967, v. 1, pp. 1988-1989.

Vdovenko, M,V, 1964. Evolution of the genus Eoparastaffella-Pseudoendothyra. Acad. Sc. Ukraine SSR, Strat. Paleont., v. 48, pp. 16-30.

Wu, X, and Chen, W, 1989, Studies on lithic facies and palaeogeography of Carboniferous in South China (Middle and Upper Yangtze region). In: XIe Congrès Int. Strat. Géol. Carbonifère Beijing, 1987, Compte Rendu, v. 4 , pp. $127-134$.

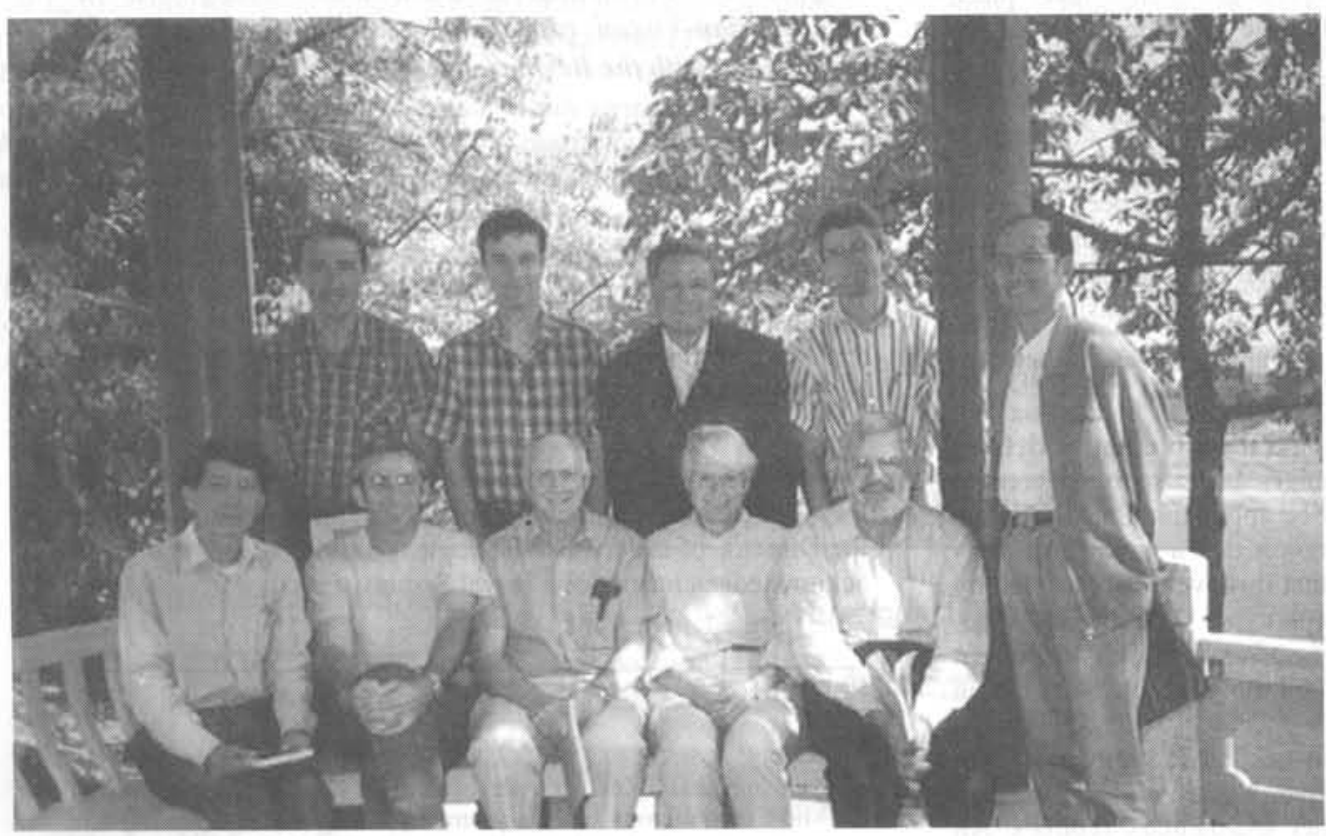

From left to right, background: T. Peryt, N.J. Riley, H.F. Hou, P. Muchez; foreground: X.H. Wu, L. Hance, J. Roberts, E. Paproth, M. Coen, Z.T. Liao. They gathered in Liuzhou, China on discussion after the field trip in 1996. J. Roberts is the Chairman of the Subcommission on Carboniferous Stratigraphy (Photograph by P.L. Brenckle).
Luc Hance, born in 1956, is graduated from the University of Louvain-la-Neuve (Belgium) and was a student of Raphaël Conil. He is now a Senior Geologist at the Geological Survey of Belgium and Professor of micropaleontology at Geography-Geology Department of the Catholic University of Louvain, Belgium. His main researches concern the Upper Devonian and Dinantian foraminiferal biostratigraphy and sedimentary history. He is a member of the TournaisianViséan Boundary Working Group. 